Compared with this, routine teaching of biology in the grammar schools has an academic flavour, with emphasis almost wholly on the 'essentials' of the subject, hinged as it is on the twin pillars of School and Higher School Certificate. Although the sylla. buses for these examinations are gradually being altered in accordance with modern views, their present scope and outlook find clear reflexion in a new text-book of biology by W. F. Wheeler for the School Certificate. Judged by text-book standards, he has achieved a useful piece of work. Apart from minor slips of emphasis and fact, the subject-matter is sound, well set out upon the page and supplemented with many helpful diagrams and photographs. The practice of reproducing line drawings giving details not referred to in the text is, however, open to question, and so is that of including material considerably more advanced without indicating at what stage it will be required. The lot of the young pupil will not be made any easier by the involved language in which the subject-matter is expressed, for it is by no means simple English. As for presentation, the author has given special prominence to human anatomy and physiology, with a useful section on human reproduction. The rest of the book follows the type method of description, both for animals and plants, so that function follows structure, although towards the end there are short chapters on such subjects as the organism and its environment, growth and multiplication, and evolution and classification.

Yet, with its concentration on 'essentials', the book conveys a curious picture of the living world. It is for the most part a two-dimensional picture of morphological and histological details, each with its appropriate technical term duly emphasized in heavy print. It is a picture lacking in unity, purpose or emotional appeal, detached on one side from personal responses to the riches of wild Nature; and on the other from the interests and needs of man, whether material, social or philosophical. To points such as these Mr. Wheeler may justly reply that they do not fall within the syllabus. To that extent the School Certificate is in danger of leaving biological thought in a state of arrested adolescence. Are these 'essentials' really so necessary; and what is their educational significance?

R. WEATHERALI

\section{THE LINNEAN HERBARIUM}

\section{A Catalogue of the Linnean Herbarium} Compiled and annotated by Spencer Savage. Pp. $\mathrm{xv}+225$. (London: Linnean Society of London, 1945.) 40s. net.

T HE Linnean Society of London has been well served by its historians and cataloguers. The late Dr. B. Daydon Jackson, general secretary from 1902 until 1926 and curator of the Linnean Collections during 1926-27, the late Lieut.-Colonel A. T. Gage, assistant secretary and librarian from 1924 until 1929, and Mr. S. Savage, the present assistant secretary and librarian, have been notable recorders of the history of the Society and have done much to make the Linnean collections serve their full purpose in taxonomy. Daydon Jackson published in 1907 (in the Proceedings of the Linnean Society) an article "On a Manuscript List of the Linnean Herbarium" to which was appended 2 "List of the Genera in the
Linnean Herbarium". As a supplement to the Proceedings for the 124th Session, 1911-12, he published an "Index to the Linnean Herbarium". In both of these works there is much information of value to those wishing to consult the collections. Neither, however, is a catalogue even approximating in scope to that prepared by Mr. Savage.

The present work is not only a list of the specimens in the Linnean Herbarium but also "includes, with as much detail as was considered necessary, the inscriptions up to the time of Sir James Smith's death in 1828-i.e., before the Herbarium came into the Linnean Society's possession". The sequence of the Catalogue is the same as that of the Herb. arium.

A great deal of trouble has been taken by $\mathrm{Mr}$. Savage to interpret the various signs used by Linnæus. Six of these signs are of special importance since they probably indicate geographical areas from which the specimens were obtained. It is suggested that Linnæus's liking for brevity was linked with a certain amount of secrecy in dealing with Russian specimens, including those he obtained from Asiatic Russia.

Particularly difficult and time-consuming was the correct attribution of the eighteenth-century handwritings in the Linnean Herbarium. Most of the inscriptions are in Latin and in what is termed 'Italian cursive hand', which shows various national characteristics. The following national handwritings are recorded as present in the Herbarium: Italian, French, Dutch, Spanish and Portuguese, Swiss, Russian, German and Austrian, Swedish, and British. Much of what Mr. Savage has to say on these handwritings will be of value to biologists who have to read and interpret manuscripts and labels written in the eighteenth century. The difficulties of inter. preting such handwritings are numerous. One learned Swede wrote three distinct handwritings"a script hand for Swedish, an Italian cursive hand for Latin, and a form of Court hand for ceremonial occasions". Linnæus's own handwriting is often very difficult to read and deteriorated considerably in his later period. $\mathrm{He}$ more and more sacrificed legibility to speed and tended to omit portions of letters. In the present Catalogue are photographic reproductions of seventy-two specimens of handwriting, mostly about half size. These make a valuable and interesting series.

Naturally much of what Mr. Savage records has a bearing upon the sometimes difficult problem of the typification of Linnæus's species. $\mathrm{He}$ does not, however, enter into details. He records that "Linnæus 'wrote up' specimens, but by no means entirely, on a 'type specimen' basis. He sometimes wrote the species number only on an added sheet, but there are many instances where several sheets have been 'written up' by him." Examination of specimens in the Linnean Herbarium does not eliminate the need for a careful study of Linnæus's descriptions and of the synonyms cited by him. The existence at the British Museum (Natural History) of Clifford's herbarium, upon which Linnæus's "Hortus Cliffortianus" is based, must not be forgotten. In fact, it is not sufficiently consulted in the 'nailing down' of Linnean species by typification.

Mr. Savage is to be thanked for the arduous task he has brought to completion, and the Linnean Society praised for the publication of the Catalogue in times so difficult as those of the present.

W. B. TURrILL 